\title{
Rumah ramah rubella sebagai kelompok dukungan online di facebook
}

\author{
Rino Andreas ${ }^{1}$, Rina Sari Kusuma ${ }^{2}$ \\ ${ }^{1}$ Universitas Gadjah Mada, Jogyakarta, Indonesia \\ ${ }^{2}$ Universitas Muhammadiyah Surakarta, Surakarta, Indonesia
}

\begin{abstract}
ABSTRAK
Situs jejaring sosial dapat membentuk interaksi sebuah komunitas atau kelompok dukungan online (KDO). KDO merupakan komunitas yang dibentuk dengan tujuan yang sama terkait topik tertentu. Kelompok ini tidak terbatas tempat, waktu, ideologi, status sosial, ekonomi maupun pendidikan. Oleh karena itu, interaksi di dalamnya jauh lebih fleksibel karena bisa berhubungan kapan saja dan dari mana saja. KDO sangat berguna untuk menghubungkan individu dengan orang-orang lain yang memiliki masalah kesehatan serupa. Salah satu bentuk KDO dalam situs jejaring sosial adalah grup Facebook Rumah Ramah Rubella. Penelitian ini bertujuan mengetahui pemanfaatan grup Facebook oleh Rumah Ramah Rubella sebagai kelompok dukungan online. Jenis penelitian yang digunakan dalam penelitian ini yaitu kualitatif dengan menggunakan pendekatan analisis isi kualitatif. Sumber data diambil dengan menggunakan teknik purposive, yakni 809 postingan wall dan komentar pada grup Facebook Rumah Ramah Rubella yang dihitung secara manual, selama dua bulan periode kampanye imunisasi MR di Indonesia yaitu Agustus sampai September. Teknik analisis data yang digunakan adalah teknik analisis isi kualitatif menggunakan data koding dengan kategorisasi induktif. Hasil penelitian yang ada dalam grup Facebook menunjukkan bahwa fitur grup Facebook berupa status, gambar, video maupun akses file, bermanfaat dalam sarana dukungan sosial secara online berupa dukungan informasi, dukungan emosional, ruang terbuka ekspresi diri dan sarana promosi terkait dengan Campak dan Rubella, imunisasi MR, maupun penyakit secara umum.
\end{abstract}

Kata-kata kunci: analisis isi; grup facebook; kelompok dukungan online; imunisasi, rubella

\section{Rumah ramah rubella as online support group on Facebook}

\begin{abstract}
Social networking sites can connect through a community or Online Support Group (OSG) mediated by computer. KDO is a community formed with the same goals related to a particular topic, no borders by space, time ideology, sosial status and education. So the user can communicate every where and any time. KDO can connecting the user with other peoples who have similar health problems. Group Facebook Rumah Ramah Rubella is KDO in social networking sites, this study aims to examine Rumah Ramah Rubella in utilizing Facebook group as $K D O$. The type of research used in this research is qualitative by using qualitative content analysis approach. The data source was taken using a purposive technique, 809 wall posts and comments on Rumah Ramah Rubella Facebook group, which was calculated manually, during the two-month MR immunization campaign period in Indonesia, from August to September. Technique of data retrieval using documentation study by take screenshoot. While the data analysis techniques using content analysis with data coding inductive categorization. The results of research in the Facebook group show that Facebook group's features of status, image, video and file access used by group members in online social support facilities to give some information support, emotional support, self expression and promotion about Measles and Rubella, Immunization and another diseases.
\end{abstract}

Keywords : content Analysis; facebook group; online support group; immunization, rubella

Korespondensi: Rino Andreas, S.I.Kom. Universitas Gajah Mada. Jl. Teknika Utara, Pogung Kidul, Sinduadi, Kec. Mlati, Kabupaten Sleman, Daerah Istimewa Yogyakarta 55281.Email: rinoandreas@mail.ugm.ac.id 


\section{PENDAHULUAN}

Rubella, merupakan penyakit berbahaya dan menjadi salah satu masalah kesehatan yang memerlukan tindakan pencegahan secara efektif. Campak dan Rubella telah menjadi salah satu kasus kesehatan dengan penderita tertinggi di Indonesia. Diperkirakan, terdapat 23.164 kasus Campak dan 30.463 kasus Rubella di tahun 2010 sampai dengan 2015. Angka tersebut masih rendah dibandingkan dengan yang terjadi di lapangan karena masih banyak kasus yang belum terlaporkan. Berdasarkan data Kemenkes selama lima tahun terakhir, Rubella berpotensi besar menyerang anak-anak maupun dewasa. Kelompok usia kurang dari 15 tahun rentan terjangkit Rubella dengan angka presentase kurang lebih 70\%. Gejala Rubella yang terjadi pada anak umumnya hanya demam dan dalam beberapa kasus tidak menunjukan gejala sama sekali. Sedangkan pada wanita dewasa hanya mengakibatkan rasa nyeri atau Arthritis. Sementara itu, Rubella pada wanita hamil memilki resiko besar sehingga dapat mengakibatkan abortus atau bayi lahir dengan (CRS) congenital rubella syndrome (Kemenkes, 2018).

Kegiatan imunisasi secara massal melalui kampanye imunisasi Measles Rubella (MR) menjadi upaya untuk menghentikan penyebaran Campak dan Rubella pada anak usia 9 bulan sampai 15 tahun. Kegiatan kampanye imunisasi MR menjadi kesempatan untuk menutupi kesenjangan yang terjadi di daerah yang rawan terjadi penularan. Di Indonesia, program kampanye imunisasi MR dibagi 2 tahap. Tahap pertama dilaksanakan di Jawa pada bulan Agustus sampai September 2017, sedangkan tahap kedua dilaksanakan pada bulan Agustus sampai September 2018 di seluruh Sumatera, Kalimantan, Sulawesi, Bali, Nusa Tenggara, Maluku dan Papua. Penyelenggaraan imunisasi Measles Rubella (MR) bertujuan untuk menurunkan resiko anak mengalami kecacatan, bahkan kematian akibat kerusakan otak, ketulian, kebutaan dan penyakit jantung bawaan.

Upaya untuk menangani Rubella ternyata bisa dilakukan bukan hanya dengan komunikasi tatap muka namun dengan memanfaatkan situs jejaring sosial. Situs jejaring sosial seperti Facebook memiliki pengguna yang bertambah setiap tahunnya. Berdasarkan situs alexa.com, Indonesia menjadi salah satu negara yang sering mengunjungi Facebook (Mala, 2016). Salah satu fitur yang ada di situs jejaring sosial Facebook adalah pembuatan grup online. Grup Facebook berbeda dengan halaman Facebook. Grup Facebook biasanya digunakan untuk keperluan diskusi bersama, sedangkan halaman Facebook digunakan untuk kepentingan sebuah organisasi resmi. Keduanya memfasilitasi diskusi namun 
halaman Facebook lebih dirancang untuk menjadi profil resmi seperti selebriti, merk dagang, atau perusahaan. Sedangkan grup Facebook adalah sarana komunikasi orangorang untuk berbagi informasi dan gagasan yang siapapun bisa membuatnya sesuai topik secara inklusif.

Seiring berkembangnya teknologi, situs jejaring sosial terus menambahkan sejumlah fitur dan fasilitasi interaksi sosial untuk penggunanya, seperti pesan pribadi dan obrolan real time, termasuk fitur grup yang telah terintegrasi untuk meningkatkan konektivitas di antara penggunanya (JE, 2014).

Facebook sebagai bagian dari Computer Mediated Communication (CMC) merupakan penanda perubahan era teknologi dan sosial yang menciptakan komunikasi baru. Sebelumnya, bentuk komunikasi terdiri dari komunikasi intrapersonal, interpersonal, kelompok maupun komunikasi massa. Dengan perkembangan teknologi, proses komunikasi kemudian termediasi menggunakan sarana komputer. CMC sendiri merupakan sebuah pendekatan yang melihat interaksi yang terjadi dengan menggunakan komputer dari interdisiplin teori yang berfokus pada kombinasi dari manusia, teknologi, proses, dan efek (Octavianti, 2012). Komunikasi dalam bentuk baru melalui CMC, terjadi ketika dua pihak atau lebih saling bertukar informasi melalui media komputer atau smartphone. Interaksi ketika menerima atau mengirim email, download, upload gambar maupun video juga bisa dikategorikan sebagai komunikasi baru (Pratiwi, 2014).

CMC merujuk pada suatu proses tempat manusia menciptakan, mengubah dan mempersepsikan informasi dengan menggunakan sistem telekomunikasi jaringan yang memfasilitasi terjadinya encoding, transmitting dan decoding suatu pesan. Tidak hanya terjadi secara one to one, CMC dapat dikembangkan untuk berkomunikasi secara many to many tergantung dari bagaimana menggunakannya. Dengan demikian CMC dapat dijadikan wahana bagi pembentukan komunitas bersama. Dalam perspektif ini, komputer merupakan sarana untuk masuk dalam jaringan cyber. Ruang-ruang berdimensi computer (CMC) memiliki arti yang sama dengan cyberspace yang mengacu pada data, informasi, diskusi, ekspresi dan perasaanperasaan yang timbul dalam diskusi dengan sesama anggota. Saat ini, keterhubungan antar individu baik secara one to one, one to many dan many to many sudah dapat terselenggara melalui berbagai fasilitas dalam ruang yang terkoneksi internet. Keterhubungan dan pembentukan jaringan antar pengguna ini bersifat asyncronous maupun synchronous. CMC menyediakan ruang baru bagi pembentukan keterhubungan antar manusia tanpa batasan waktu dan tempat 


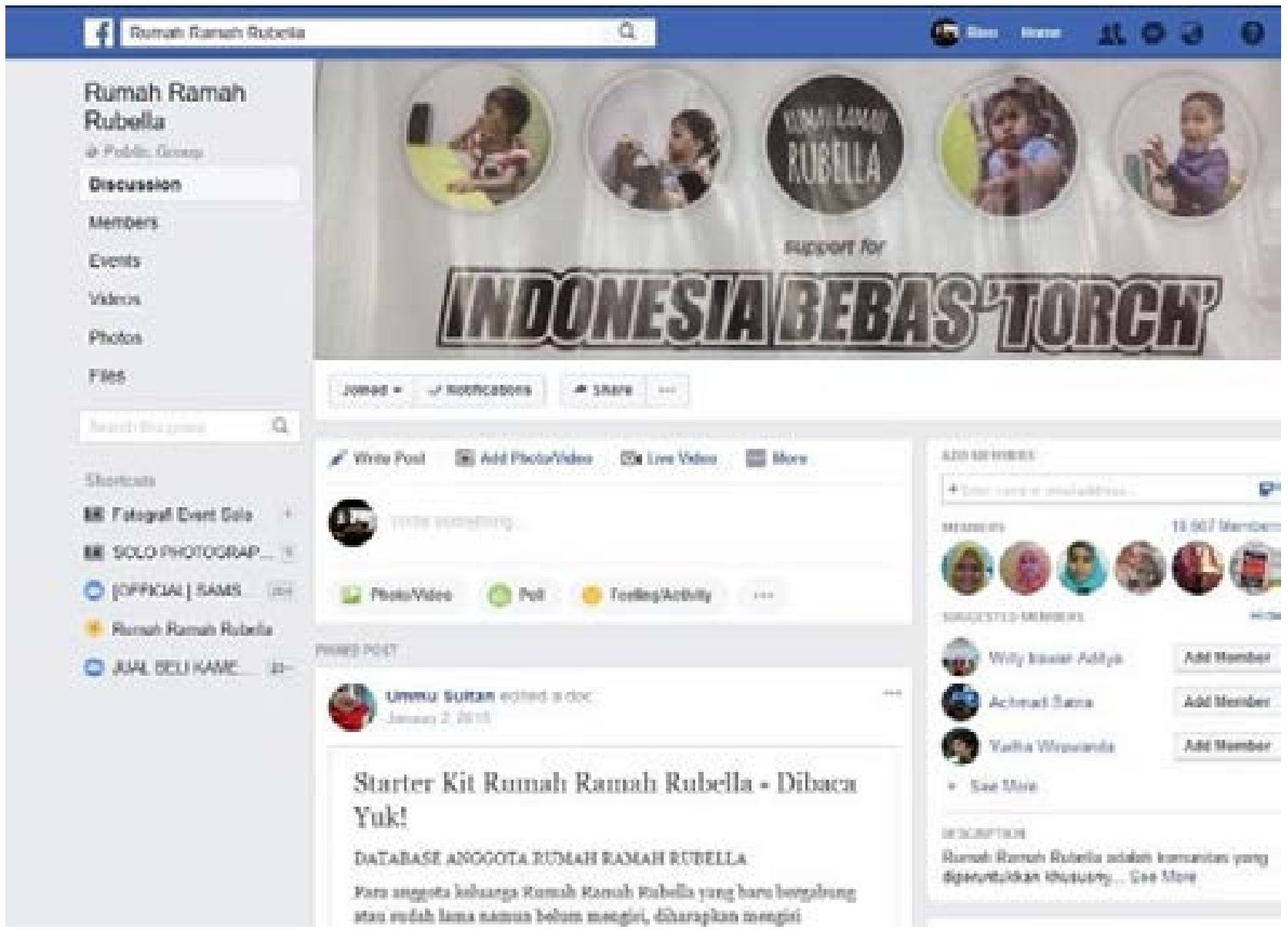

Sumber: Facebook, 2018

\section{Gambar 1 Facebook Rumah Ramah Rubella}

(Prasetyo, 2010).

Penggunaan grup Facebook sebagai kelompok dukungan online (KDO) dibuat sebagai wadah diskusi dan dukungan untuk berbagi informasi yang berhubungan dengan kesehatan. Grup Facebook Rumah Ramah Rubella seperti pada gambar 1 menjadi wadah untuk berbagi pengalaman, membagikan pesan persuasi dan berbagi informasi mengenai berbagai penyakit, khususnya Rubella. Komunitas online yang didirikan oleh Grace Melia pada tanggal 2 Oktober 2013 ini, sekarang telah mencapai lebih 21.445 anggota dan terus bertambah. Grup ini dimoderatori oleh 6 orang admin yang memiliki akses lebih. Anggota grup terdiri dari berbagai kalangan, bukan hanya orang tua, melainkan juga orang-orang yang peduli pada pencegahan penyakit Rubella, termasuk terapis dan dokter yang biasanya ikut membantu menjawab pertanyaan anggota, hingga pengguna yang memiliki anak dengan riwayat TORCH (istilah yang mengacu kepada infeksi yang disebabkan oleh Toksoplasma, Rubella, Cytomegalovirus (CMV) dan Herpes simplex virus II (HSV-II) pada wanita hamil).

Rumah Ramah Rubella merupakan grup yang mengharuskan penggunanya bergabung terlebih dahulu dan disetujui administrator 
untuk dapat melihat, mengirim atau mengakses file yang ada didalamnya. Rumah Ramah Rubella menjadi komunitas yang terbuka untuk siapapun dengan mematuhi aturan yang telah disepakati. Wood dan Smith (2005: 233) menjelaskan komunitas virtual sebagai lingkungan termediasi computer, tempat dimana para pengguna membagi kesepahaman mereka dan saling membangun relasi (Rahmania \& Pamungkas, 2018).

Pengguna Facebook yang telah menjadi anggota grup Rumah Ramah Rubella, dapat mengirimkan postingan maupun berkomentar. Kiriman wall dan komentar anggota tersebut mengandung pesan yang dapat diintepretasikan dengan teknik analisis isi. Analisis isi dipelopori oleh Harold D. Lasswell yang dapat dijelaskan dengan teori 5 unsur komunikasi yaitu who, says what, to whom, in which channel, with what effect (Aldita, 2014). Pesan yang dikirimkan anggota grup berupa status foto, gambar, video dalam situs jejaring sosial ditanggapi oleh anggota lain sebagai bentukfeedback. Feedback Pesan tersebut dapat menimulkan effect tertentu, dalam hal ini terkait topik kesehatan khusunya Campak dan Rubella.

Facebook telah menjadi platform populer untuk mendorong partisipasi pengguna mengenai topik kesehatan karena lebih interaktif dibanding media lain. Dalam jurnal Communicating About Cancer Through
Facebook: A Qualitative Analysis of a Breast Cancer Awareness Page dijelaskan bahwa kampanye kanker payudara yang dilakukan di negara Amerika melalui penggunaan halaman Facebook, bertujuan untuk meningkatkan kesadaran bahaya kanker payudara, promosi produk, dan penggalagan dana untuk wanita yang membutuhkan serta berisi informasi kesehatan (Abrahamson, Keefe, \& Chou, 2015).

Sebuah artikel ilmiah berjudul "Social Networking in Online Support Groups for Health: How Online Social Networking Benefits Patients" menunjukkan bahwa sekitar sepertiga pencari informasi kesehatan secara online telah menggunakan situs jejaring sosial untuk masalah kesehatan. Jumlah orang yang menggunakan situs jejaring sosial untuk bantuan informasi kesehatan diperkirakan akan terus meningkat tiap tahunnya (JE, 2014).

Situasi itu dipertegas dalam tulisan Digital Divide 2.0: The Role of Social Networking Sites in Seeking Health Information Online From a Longitudinal Perspective bahwa situs jejaring sosial memiliki implikasi yang besar untuk komunikasi kesehatan karena dengan fitur teknologi situs jejaring sosial saat ini sangat memberdayakan para penggunanya dengan menyediakan platform dan alat untuk membangun relasi sosial. Secara umum, anggota situs jejaring sosial dapat memposting dan membaca pesan, menemukan sumber 
informasi, belajar tentang penyakit, perawatan, pilihan pengobatan, dan juga interaksi yang lebih personal dengan pengguna lain menggunakan komponen situs jejaring sosial (Feng \& Xie, 2014). Beberapa situs jejaring sosial yang ada antara lain Facebook, MySpace, Twitter, Instagram dan lain sebagiannya. Facebook menjadi salah satu situs jejaring sosial yang paling popular saat ini karena penggunanya mengalami peningkatan dari waktu ke waktu. Banyak fitur yang ditawarkan Facebook dalam rangka memudahkan interaksi.

Kelompok dukungan online (KDO) dalam Facebook dapat mempertemukan orang-orang baru. Banyak kelompok dukungan online memberikan informasi yang tidak dapat ditemukan di tempat lain (Barker, 2008). Anggota kelompok dapat mencari pendapat dari orang lain, termasuk membahas pilihan pengobatan, efek samping, dan gejala kesehatan dengan orang yang benar-benar memiliki pengalaman secara lansung. Keuntungan berpartisipasi dalam kelompok pendukung online, serupa dengan manfaat bergabung dengan kelompok tatap muka. Pengguna dapat menerima informasi, dukungan emosional, empati, bimbingan, untuk perbaikan mekanisme penanganan kesehatan diri. Ada juga manfaat lain adanya kelompok dukungan online, seperti kenyamanan, anonimitas, dan pilihan respons yang beragam, yang tidak dapat ditemukan dalam kelompok tatap muka (Turner, 2017).

Sedangkan dalam artikel jurnal "Utilizing the Uses and Gratification Theory to Understand Patients Use of Online Support Groups" tahun 2014 dikatakan bahwa penggunaan KDO dapat dilakukan tanpa batasan ruang dan waktu, berbeda dengan kelompok dukungan offline yang mengharuskan komunikasi face to face (Kisekka, Han, \& Sharman, 2014). Oleh karena itu, KDO memberikan rangkaian kesempatan unik bagi penggunanya. Kemampuan KDO untuk memberi manfaat bagi pengguna juga tergantung pada beberapa faktor utama, seperti kehadiran orang-orang di kelompok dukungan online (KDO) untuk menawarkan dukungan, kehadiran fitur seperti forum dan fungsi chat yang memfasilitasi komunikasi, dan kemauan pengguna untuk menawarkan dukungan. Partisipasi pada KDO sangat penting bagi keseluruhan anggota kelompok. Oleh karena itu, situs jejaring sosial tidak hanya menarik bagi pengguna, tetapi juga mendorong adanya interasi dan partisipasi. Dalam konteks KDO, anggota mendapat manfaat dari partisipasi aktif pada KDO.

Lebih lanjut, dalam jurnal Online Support Groups: The Good, the Bad, and the Motivated tahun 2017, pengguna kelompok dukungan online (KDO) dapat berpartisipasi untuk medapatkan dukungan secara emosional dan psikologis (Turner, 2017). Anggota kelompok 
merasa nyaman mendiskusikan perasaan dengan orang lain yang memiliki masalah serupa. Kelompok dukungan online (KDO) dan tatap muka adalah tempat di mana orang dapat berbagi emosi dan pengalaman, melampiaskan rasa frustrasi, dan mendiskusikan perjuangan sehari-hari, dengan orang lain yang mengalami keadaan serupa. KDO membantu pengguna merasa menjadi bagian dari grup. Kelompok pendukung dapat menjadi sumber dorongan, memberikan optimisme dan dorongan untuk bertahan, terutama jika dalam realitasnya anggota grup memiliki harapan yang rendah terhadap proses pemulihan(JE, 2014). Pengguna bergabung dengan kelompok dukungan untuk belajar mengatasi masalah kesehatan dan cara untuk terus maju dalam realitas. Lebih lanjut Walther menjelaskan bahwa dalam hal kepuasan, diskusi kelompok yang dimediasi komputer memberikan tingkat kepuasan dan hubungan yang sama dengan komunikasi face to face (Widiasari, 2016).

Penelitian sebelumnya mengungkapkan bahwa situs jejaring sosial seperti Twitter sebagai kelompok dukungan online, menawarkan penderita kanker untuk terhubung dengan penderita lain setiap saat, siang atau malam dari hampir semua tempat di dunia. KDO dapat menangani ketidakpastian, rasa sakit fisik, dan ketegangan emosional bagi para penggunanya dengan memanfaatkan fitur seperti berbagi pesan dan keberadaan hyperlink dan ekspresi emosional. KDO kanker berbasis Twitter, terus tumbuh dan berkembang. Semakin banyak orang yang beralih ke jejaring sosial untuk mendapatkan dukungan informasi maupun emosional terkait topik kesehatan (Myrick, Holton, Himelboim, \& Love, 2015).

Berdasarkan latar belakang dan beberapa penelitian terdahulu tersebut, maka penelitian ini berupaya untuk mengetahui bentuk dukungan yang ada dalam grup Facebook Rumah Ramah Rubella sebagai kelompok dukungan online (KDO) terkait kegiatan kampanye imunisasi Rubella di Indonesia. Selain itu, peneliti juga akan melihat seberapa jauh dukungan secara online tersebut menjadi dorongan anggota grup untuk mengetahui permasalahan kesehatan khususnya imunisasi MR.

\section{METODE PENELITIAN}

Berdasarkan masalah yang akan diteliti, jenis penelitian ini menggunakan pendekatan kualitatif. Populasi penelitian adalah postingan kelompok dukungan online Rumah Ramah Rubella di Facebook. Dalam penelitian ini, teknik yang digunakan untuk menentukan sumber data penelitian adalah menggunakan teknik purposif, di mana pengambilannya ditentukan karena sebagai sumber yang kaya akan informasi sesui dengan masalah yang diteliti (Sugiyono, 2016). Sumber data yang 
digunakan adalah 809 kiriman wall dan isi komentar Facebook "Rumah Ramah Rubella" selama 2 bulan yaitu Agustus sampai September 2017 karena selama periode tersebut adalah masa kampanye imunisasi Measles Rubella (MR) di Indonesia.

Teknik pengumpulan data melalui dokumentasi yang terdiri dari data primer dan sekunder. Data primer adalah kiriman wall dan komentar grup Facebook Rumah Ramah Rubella, sedangkan data sekunder adalah data yang berasal dari buku, jurnal, dan lain sebagainya.

Teknik analisis data yang digunakan adalah analisis isi kualitatif. Alasannya, selain pertimbangan waktu dan biaya juga sumber data mudah diperoleh. Penelitian ini menggambarkan isi postingan dan komentar dalam grup. Teknik validitas menggunakan interkoder untuk mengurangi bias dan subjektifitas peneliti dalam analisis penelitian. Peneliti dibantu oleh orang lain yang ditunjuk menjadi kode, untuk mengaudit keseluruhan aktivitas peneliti dalam melakukan penelitian. Bantuan ini juga diperlukan untuk mengukur ketepatan penilaian peneliti terhadap postingan dalam grup Rumah Ramah Rubella. Pertimbangan pemilihan interkoder dalam penelitian ini adalah praktisi komunikasi yang memiliki kompetensi untuk mengintepretasikan data temuan, selain itu interkoder juga aktif di Facebook dan mem- follow grup Rumah Ramah Rubella. Teknik validasi penelitian ini menggunakan triangulasi peneliti.

\section{HASIL DAN PEMBAHASAN}

Berdasarkan temuan data 809 postingan yang dihitung secara manual, selama dua bulan yaitu Agustus dan September 2017, ditemukan empat jenis dukungan online yang terdapat pada halaman Facebook Rumah Ramah Rubella.

Pertama, KDO sebagai dukungan informasi. dukungan informasi merupakan salah satu bentuk dukungan sosial yang meliputi pemberian feedback, saran atau nasehat kepada orang lain. Nasehat maupun saran menjadi bentuk dukungan informasi yang diberikan oleh orang-orang yang pernah mengalami keadaan yang serupa dimana akan membantu individu memahami situasi dalam mencari alternatif pemecahan masalah atau tindakan yang akan diambil. Dalam penelitian ini dukungan informasi dibagi menjadi dua subtema antara lain, sarana tanya jawab dan berbagi informasi kesehatan (Purba, Yulianto, \& Widyanti, 2007).

Postingan grup Rumah Ramah Rubella berkaitan dengan pertanyaan dan jawaban seputar kesehatan. Pertanyaan-pertanyaan yang jumlahnya ratusan tersebut sangat beragam. Dari bahasan khusus seputar penyakit Campak dan Rubella, rekomendasi dokter, cara membaca hasil cek laboratorium, imunisasi MR 
dan lain sebagainya. Anggota grup menanyakan informasi dasar terkait imunisasi MR serta penyakit Campak Rubella. Informasi tersebut misalnya ciri-ciri atau gejala yang dialami, perbedaan antara Campak dan Rubella, cara menghindari penyakit Rubella dan lainlain. Lebih lanjut pertanyaan "Apakah virus Rubella pada orang dewasa menular", atau "Bagaimana kondisi anak yang aman sebelum di imunisasi?" ditanyakan oleh orang tua yang membutuhkan informasi dasar kesehtan tersebut. Respon yang didapat adalah komentar yang diberikan anggota lain sesuai dengan pengalamanyang serupa, atau memberikan link menuju informasi yang dibutuhkan. Namun jika dirasa masih ragu maka orang tua disarankan untuk mengkonsultasikannya ke dokter terkait, agar memiliki kepastian dan tindakan medis yang tepat.

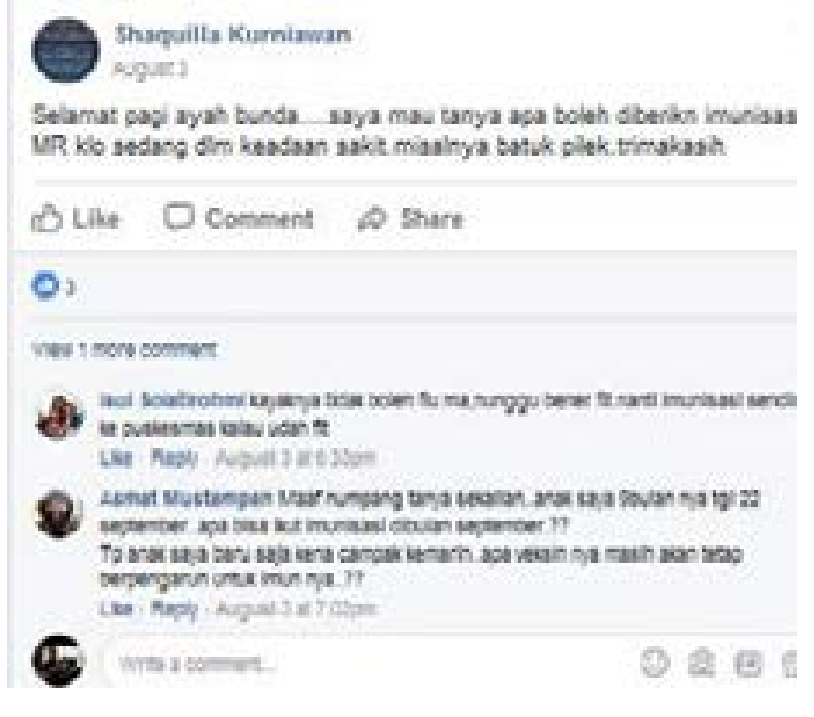

Sumber: Facebook, 2018

Gambar 2 Postingan pertanyaan
Peran admin juga terlihat melalui komentar yang memberikan saran sesuai dengan pengalaman atau dengan mengarahkan anggota untuk mengakses atau membaca file yang ada di dalam grup Rumah Ramah Rubella. File dalam grup tersebut berisikan informasi atau istilah-istilah kesehatan khususnya Campak dan Rubella yang bisa di download dan disimpan, agar sewaktu waktu bisa dibaca kembali. Aktivitas tanya jawab dalam grup sebagai bagian dari fitur jejaring sosial memungkinkan feedback yang lebih cepat. Hal itu terlihat melalui respon dalam postingan grup Rumah Ramah Rubella. Kemunculan jejaring sosial mempercepat arus komunikasi dengan mendorong kontribusi dan umpan balik dari semua orang yang tertarik dengan suatu topik, dan merupakan percakapan dua arah karena bersifat terbuka dan partisipasif (Mayfield, 2008). Anggota grup diberikan kesempatan dan akses yang sama untuk menjawab pertanyaanpertanyaan seputar kesehatan dalam kelompok dukungan online (KDO) tersebut.

Berdasarkan postingan grup, peneliti melihat berbagai informasi kesehatan yang disampaikan antara lain berkaitan dengan informasi/undangan event kesehatan seperti imunisasi MR, sosialisasi penderita autis, family support group, media literasi kesehatan dalam bentuk talkshow, workshop terapi, serta seminar diskusi. Informasi berbagai event tersebut 
berguna bagi anggota yang ingin menambah pengetahuannya seputar tema tertentu. Anggota grup dengan domisili daerah tertentu dapat menghadiri undangan acara tersebut guna memahami tindakan medis yang tepat bagi anaknya secara lebih dalam. Dengan pemateri atau pembicara yang memiliki kompetensi di bidang tersebut, informasi yang didapat bisa menjadi rujukan, dan orng tua semakin yakin dengan tindakan dan pengambilan keputusan dengan tepat.

Dalam postingan di bulan Agustus, informasi event kesehatan yang pertama diposting adalah adalah event pembukaan kampanye imunisasi MR 1 Agustus 2017 yang dibuka oleh Presiden Republik Indonesia Joko Widodo di Sleman Yokyakarta. Event ini juga menandakan informasi bahw gerakan imunisasi dimulai di Indonesia. Anggota mengomentari hal tersebut secara positif dan berharap kampanye imunisasi dalam berjalan lancar. Selanjutnya, event lain terkait imunisasi yang dibagikan seorang admin adalah event seminar dan diskusi "Imunisasi dalam Pandangan Islam” yang didukung Kemenkes RI. Hal itu dalam upaya mengajak para orang tua untuk melakukan imunisasi dan menghapus persepsi yang salah mengenai isu anti-vaksin. Peneliti melihat dengan banyaknya event yang diposting memungkinkan orang tua hadir dan menambah wawasan dalam penyembuhan penyakit dan terdorong untuk segera melakukan imunisasi MR. Lalu, event "Family Support Group" dimana para anggota dapat menghadiri acara diskusi secara langsung atau event workshop untuk anak dengan kebutuhan khusus seperti autis yang sulit berjalan dan sebagainya

Informasi lain yang disampaikan dalam masa kampanye, dibagikan dalam berbagai bentuk yaitu link, video penjelasan pakar, brosur, atau status dengan foto tertentu yang berisikan informasi kesehatan. Nasrullah mengatakan bahwa komunikasi yang terjadi di media siber lebih banyak tergantung pada teks, baik teks dalam pengertian sesungguhnya maupun simbol, ikon, atau penanda lain yang mewakili maksud dari pesan (A. M. V. Utami, Lestari, \& Putra, 2015). Contoh dari hal tersebut adalah postingan yang berjudul "Masih ragu imunisasi MR?" dengan link yang berasal dari www.idai.or.id (Ikatan Doker Anak Indonesia). Informasi yang dibagikan mencakup pengertian campak rubella, perbedaan, gejala, diagnosa, dan lainnya. Peningakatan informasi dan pengetahuan mengenai suatu penyakit dapat mempengaruhi tindakan kesehatan yang lebih efektif dalam proses penyembuhan. KDO mampu menyediakan akses informasi melalui grup Rumah Ramah Rubella.

Selain anggota grup, admin juga terlihat aktif membagikan file grup terkait materi Imunisai MR yang sumbernya berasal 
dari kementrian kesehatan RI. Respon positif yang diberikan berupa dukungan informasi, terlihat melalui komentar yang mengucapkan terima kasih atas informasi yang diberikan. Dukungan informatif yang dimaksud adalah berupa nasehat, sugesti, arahan langsung, dan informasi dalam KDO, sama halnya dengan dunia nyata. Sesuai dengan penelitian yang dilakukan Cutrona dan Suhr yang mengatakan bahwa dukungan informasi di dalamnya terdapat umpan balik dimana ada yang meminta dan ada yang menerima dukungan tersebut berupa informasi. Sejalan dengan hal itu Menurut House dukungan informasi merupakan dukungan yang bertujuan untuk memberikan informasi baik secara online maupun face to face seperti arahan maupun saran yang sifatnya informatif (Oktafiana, 2016).

Kedua, sebagai dukungan emosional. Sarafino mengatakan bahwa dukungan emosional adalah salah satu bentuk dukungan sosial yang termasuk dalam ungkapan rasa empati, kepedulian dan perhatian terhadap individu, seperti memberikan perhatian terhadap masalah yang sedang dihadapi atau mendengarkan keluhannya. Adanya dukungan ini akan memberikan rasa nyaman, kepastian, perasaan memiliki dan dicintai. Bentuk dukungan baik secara online maupun offline memiliki arti yang sama yaitu menunjukan sisi positif (Purba et al., 2007). Hal tersebut sejalan dengan pernytaan House yang mengatakan bahwa dukungan emosional merupakan bentuk dukungan yang melibatkan individu dalam menyampaikan sebuah permasalahan yang sedang dihadapinya, kemudian ditanggapi oleh individu lainnya berupa rasa simpati maupun perhatian (Oktafiana, 2016).

Berdasarkan postingan grup Rumah Ramah Rubella dukungan emosional terlihat melalui pendekatan agama, meminta doa atau mendoakan, dan menberikan pesan semangat. Anggota Kelompok dukungan online (KDO) saling memberikan feedback melalui kolom komentar yang menjadi fitur situs jejaring sosial Facebook

Dukungan emosional dengan pendekatan agama terlihat dari postingan tulisan, video maupun gambar yang dikirim anggota. Salah satunya postingan video yang berjudul "Pahala Sabar". Dalam video tersebut terlihat seorang Ustad sedang berceramah, yang mengatakan bahwa "orang yang sabar dan ikhlas dalam hidupnya diuji oleh Allah akan ditempatkan dalam surga". Ustad tersebut juga memiliki kedua kakak yang menderita downsyndrom atau berkebutuhan khusus. Dimana keadaan serupa juga dialami oleh anggota grup. Penggunaan metode ceramah dan Ustad sebagai otoritas agama juga menjadi bentuk dukungan emosional yang dapat dipercaya. Hal itu dipertegas dengan penggunaan simbol agama 


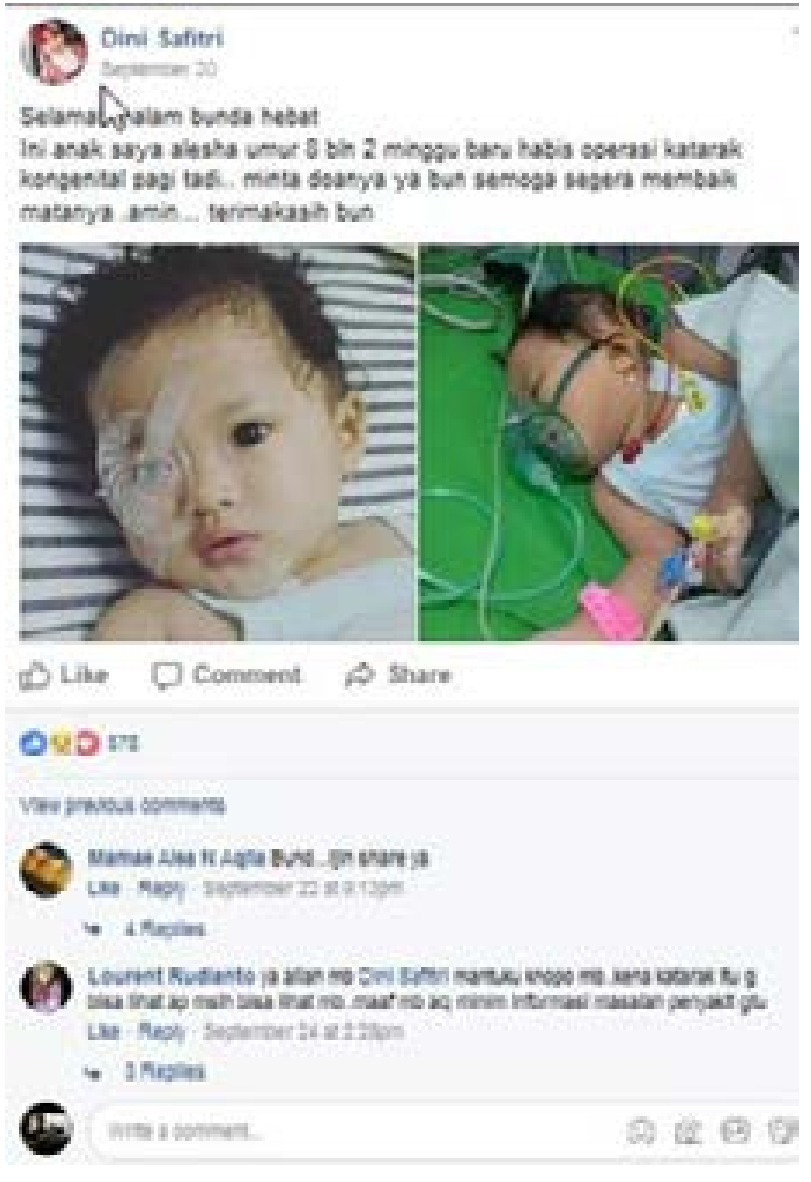

Sumber: Facebook, 2018

\section{Gambar 3 Postingan permohonan doa}

salah satunya adalah peci dan kegiatan dakwah. Peneliti melihat bahwa selama periode 2 bulan berdasarkan postingan sebagian besar anggota grup menujukan mayoritas beragama Islam.

Pendekatan agama sendiri berkaitan dengan harapan kekuatan Allah yang menentukan sebuah takdir. Selain itu berkaitan dengan pahala dan juga surga bagi yang sabar menghadapi "ujian" dalam hal ini proses penyembuhan anak penderita Rubella. Dari postingan dan komentar, anggota grup juga meminta doa untuk anaknya melalui tulisan, gambar, maupun video. Postingan doa tersebut untuk anak yang akan mendapatkan operasi, melakukan terapi, dan proses pemulihan lainnya. Kutipan tersebut menunjukkan seorang anggota menuliskan keadaan anaknya yang sedang mendapatkan ujian dari Allah (berupa penyakit) dan meminta doa agar menjadi ibu yang tegar dan sabar. Adapun bentuk perhatian atau respon positif yang diberikan anggota lain adalah komentar "amin" dan turut mendoakan agar segera pulih dan sembuh. Hal itu merupakan bentuk dukungan secara emosional berupa rasa simpati dan perhatian.

Fitur Facebook sebagai jejaring sosial memungkinkan terjadinya umpan balik langsung dan lebih interaktif. Dalam CMC selalu saja ada bahasa universal, misalnya penggunaan emoticons atau ekspresi diri di dunia siber dalam percakapan atau komunikasi yang diekspresikan melalui teks, simbol atau lambang, yang harus dipahami (Utami et al., 2015). Hal itu terlihat dalam respon anggota grup dalam kolom komentar berupa emotion sedih sebagai bentuk rasa kepedulian.

Lebih lanjut dukungan emosional juga ditujukan untuk ibu penderita agar terus semangat dan diberikan kesabaran dalam perjuangan menyembuhkan anaknya. Proses penyembuhan penyakit anak biasanya membutuhkan waktu, tenaga dan biaya yang tidak sedikit. Dukungan emosional yang didapat membuat individu merasa diperhatikan, nyaman, diperdulikan dan 
dicintai sehingga individu akan lebih mampu menghadapi masalah dengan lebih baik (Utami, 2013). Diperkuat Roffeei yang mengungkapkan bahwa dukungan emosional dapat berupa dukungan rasional (hubungan), fisik (kasih sayang), simpati, empati, dorongan, konsultasi, syukur, selamat dan doa (Lestaluhu, 2017).

Ketiga, sebagai ruang terbuka ekspresi diri. Tafjel mengatakan bahwa ruang terbuka ekspresi diri menggambarkan bagaimana individu mengekspresikan dirinya ketika berkomunikasi dengan individu yang lain. Orang lain bisa merasa lebih nyaman dan terbuka serta kemungkinan lebih jujur dalam menyampaikan pesan yang ingin disampaikan dengan orang lain. Melalui jejaring sosial, seseorang juga dapat mengekspresikan emosi tertentu yang dialaminya atau mengungkapkan diri sama seperti tatap muka dengan komunikasi yang disengaja melaui perilaku verbal yang menjelaskan tentang pengalaman atau perasaan seseorang. Kelompok dukungan online (KDO) Facebook menjadi ruang terbuka bagi anggota untuk mengekspresikan perasaan ataupun setiap emosi yang dirasakan, dengan cara senantiasa menjalin komunikasi secara rutin melalui postingan, yang kemudian dapat memicu tanggapan dari orang lain. Grup online dapat mendorong diskusi mengenai suatu topik tertentu (Fitrya, 2017).

Ruang terbuka untuk ekspresi diri dalam postingan grup Facebook Rumah Ramah Rubella dibagi menjadi lima sub tema, antara lain berbagi pengalaman tentang penyakit Rubella dan imunisasi MR, memperkenalkan anaknya, isu-isu anti-vaksin, berbagi aktivitas sehari-hari, dan berbagi cerita anaknya yang telah meninggal.

Penelitian sebelumnya dalam jurnal "Communicating about cancer through Facebook: a qualitative analysis of a breast cancer awareness page" menunjukkan bahwa jejaring sosial Fcebook digunakan sebagai ruang terbuka ekpresi diri untuk memberi atau meminta dukungan terkait kanker Payudara (Abrahamson et al., 2015). Hal itu sejalan dengan temuan peneliti dalam postingan grup Facebook Rumah Ramah Rubella yang memiliki tagline "sharing is caring" yang menunjukan bahwa anggota secara terbuka memiliki kesempatan mengekspresikan perasaannya, pengalamannya sebagai bentuk kepedulian dan dukungan.

Peneliti melihat grup Rumah Ramah Rubella memanfaatkan Facebook sebagai sarana untuk berbagi pengalaman para orang tua sebelum melakukan imunisasi Rubella. Orang tua menujukan kekhawatiran mengenai kondisi yang "aman” untuk anaknya yang siap di imunisasi. Misalnya ketika anak "bapil" atau batuk pilek yang membuat orang tua belum yakin untuk melakukan imunisasi. Hal tersebut ditanggapi anggota lain berdasarkan 
pengalaman mereka melalui kolom komentar yang mengatakan bahwa Imuniasasi dapat dilakukan ketika anak mengalami bapil asalkan tidak demam. Ada pula anggota lain yang menyarankan untuk mengkonsultasikannya lebih lanjut kepada doketr terkait, sehingga dapat mengambil keputusan yang tepat.

Selain itu, ada pula postingan anggota grup sesudah melakukan imunisasi MR. Postingan tersebut terdiri dari foto maupun tulisan yang menggambarkan kondisi anak yang pasca-imunisasi. Ada yang menangis, adapula yang senang karena mendapatakan hadiah dari dokter atau bidan. Dalam postingan juga terlihat harapan para orang tua setelah melakukan imunisasi kondisi anaknya akan lebih membaik. Hal itu sejalan dengan penelitian sebelumnya, dimana jejaring social dimanfaatkan sebagai media berbagi cerita pribadi, pengguna menggunakan Facebook untuk mengekspresikan pendapat pribadi mengenai pencegahan, gejala, pengobatan, dan topik terkait kesehatan (Abrahamson et al., 2015).

Cyberspace dalam CMC terlihat ketika para anggota saling berbagi pengalaman secara virtual. Rheingold mengatakan bahwa, keberadaan ruang siber selalu terkait dengan komunitas virtual, yaitu mereka yang saling berinteraksi menggunakan teknologi komputer karena melalui interaksi antar pengguna, ruang itu terbentuk. Anggota masyarakat maya tidak terikat secara territorial atau bahkan tidak pernah bertemu muka sekalipun. Melalui sarana virtual mereka berinteraksi, mempertukarkan makna dan membangun realitas dunia (Prasetyo, 2010).

Bentuk ekepresi diri selanjutnya yang dilakukan anggota kelompok dukungan online (KDO) adalah memperkenalkan anaknya. Hal itu terlihat dengan postingan tulisan, gambar atau video. Biasanya tulisan terkait nama anak, umur, riwayat penyakit seperti Cerebral Palsy, Microsepaly, Minenggocele Chepalus, Sceepch delay dan kekurangan fisik lainnya. Sedangkan gambar dan video yang dikirimkan menggambarkan kondisi anak. Perjalanan pengobatan yang dilalui anak penderita diekspresikan orang tuanya sehingga lebih dekat dengan anggota lain yang memiliki kondisi serupa. Mengungkapkan informasi dengan orang lain, disebut sebagai pengungkapan diri dengan mengungkapkan apa adanya. Ini disebut juga “pengungkapan deskriptif” karena mendeskripsikan beberapa hal tentang diri anak agar lebih dikenal (Fitrya, 2017).

Dukungan yang diberikan anggota lain terlihat dari komentar yang memberikan semangat atau memberikan like "reaksi sedih" sebagai bentuk rasa empati. Salah satu postingan, seperti gambar 4 di atas, menunjukan like hingga 1.100 lebih. Adapula komentar yang menunjukkan adanya pemberikan apresiasi 
terhadap postingan pesan dengan memberikan pujian kepada anaknya. Like atau share menjadi bentuk perhatian anggota kelompok dukungan online (KDO).

Lebih lanjut, perkenalan yang dilakukan oleh orang tua menjadi bentuk ekspresi keterbukaan diri didunia maya yang relatif aman. Hal itu sejalan dengan Littlejohn \& Foss yang menyatakan bahwa kemampuan CMC untuk mengirimkan isyarat non-

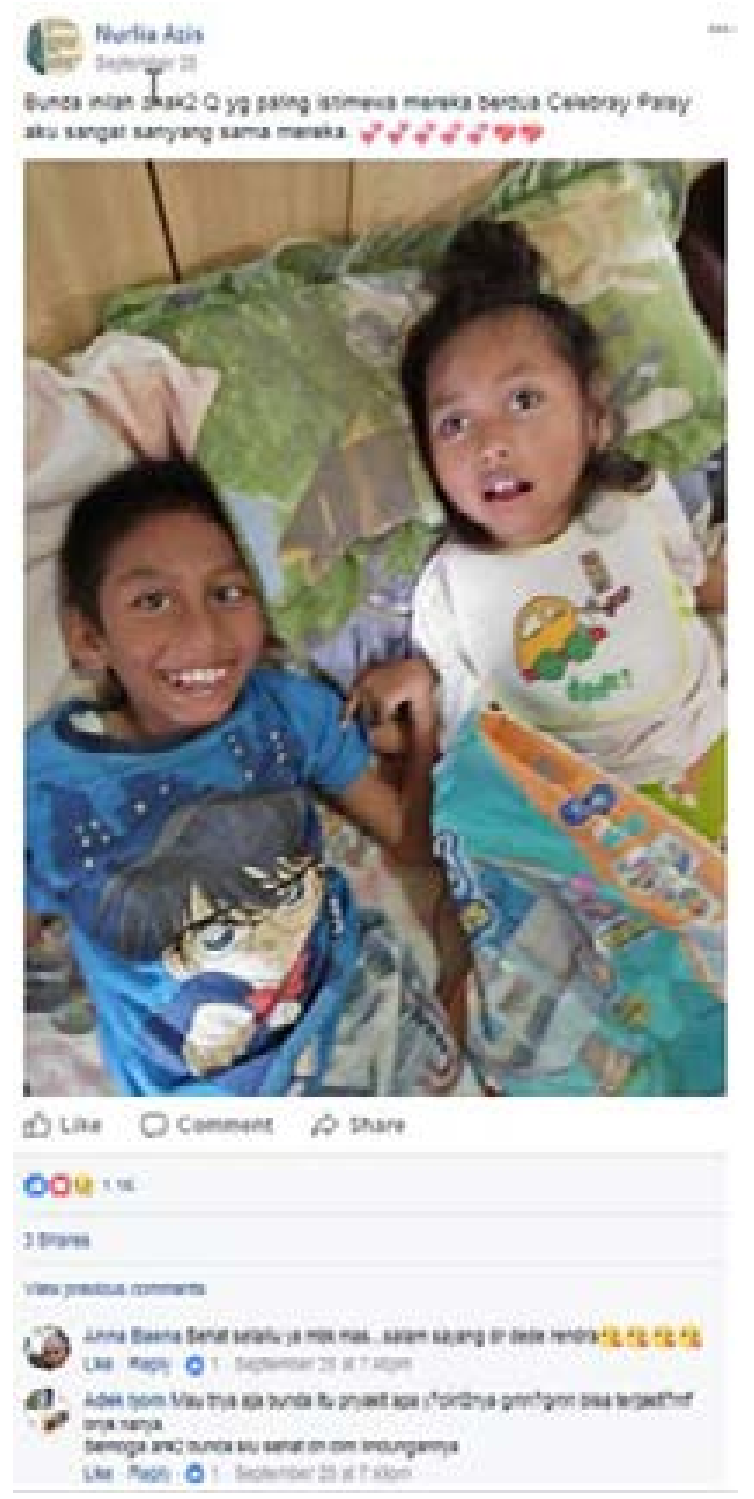

Sumber: Facebook, 2018

Gambar 4 Postingan perkenalan anak verbal yang lebih sedikit merupakan sebuah keuntungan. Turkle melihat bahwa CMC merupakan wadah emansipasi. Di mana media komputer memungkinkan penggunanya untuk mengeksplorasi identitas mereka dalam realitas sosial dan fisik yang relatif aman (Widiasari, 2016).

Selain topik kesehatan terkit Imunisasi Campak dan Rubella. Anggota grup juga aktif mendiskusikan vaksinasi. Vaksinasi adalah proses memasukkan vaksin ke tubuh manusia untuk mendapatkan efek kekebalan terhadap penyakit tertentu. Vaksin itu sendiri merupakan bakteri dan virus yang telah dilemahkan. Sebenarnya vaksinasi merupakan bagian dari imunisasi. Ini merupakan tindakan yang dilakukan sebelum imunisasi (Santoso, 2017).

Ruang ekspresi diri juga menunjukkan kekhawatiran orang tua dengan isu yang sedang beredar yaitu isu anti-vaksin. Hal itu terjadi karena banyak anggapan bahwa imunisasi tidak perlu dilakukan karena beberapa alasan antara lain, imunisasi dianggap haram bagi penganut agama Islam karena mengandung babi (Fadhila, 2017), atau isu bahwa imunisasi hanyalah bisnis, sehingga isu tersebut membuat anggota grup menjadi terganggu dalam mengajak imunisasi para orang tua yang lain. Kolom komentar mengenai postingan isu antivaksin tersebut, menjadi sarana diskusi anggota untuk berbagi pendapat. Adapula anggota yang 
menantang para anti-vaksin yang sehat agar tertular virus Rubella yang membahayakan agar dapat membuktikan bahwa imunisasi penting untuk dilakukan. Hal tersebut merupakan bentuk ekspresi anggota yang memiliki sudut pandang berbeda terkait vaksin. Berdasarkan komentar anggota saling menguatkan, sabar dan menggunakan energinya untuk keperluan ynag lebih penting yaitu proses penyembuhana anaknya daripada hanya berdebat.

Adanya orang-orang yang anti terhadap vaksinasi mengundang reaksi para orang tua yang memperjuangkan anaknya untuk kesembuhan. Isu anti vaksin yang diposting salah satu angota grup, menunjukan sumber sebuah jurnal kesehatan, namun berdasarkan komentar terlihat bahwa Jurnal rujukan yang digunakan merupakan jurnal yang sudah tidah relevan. Proses translate atau penerjemahan jurnal tersebut salah serta kutipan yang mennjukan masalah isu anti vaksin hanyalah sepotong dan tidak lengkap. Anggota yang menjelaskan hal tersebut berusaha untuk mempertahankan persepsi anggota grup lain agar tetap melakukan proses vaksin kepada anaknya. KDO membantu pengguna merasa menjadi bagian dari grup. Kelompok pendukung dapat menjadi sumber dorongan, dan memberikan optimism (JE, 2014).

Kelompok dukungan online (KDO) Facebook menjadi sarana diskusi yang efektif terkait isu tertentu salah satunya isu-anti vaksin. Walther mengatakan bahwa diskusi dengan CMC menghasilkan partisipasi yang lebih setara dalam penyampain ide dan gagasan dibandingkan diskusi FtF. CMC memiliki fitur alamiah untuk mendemokratisasi komunikasi kelompok. Dalam hal kepuasan dan hubungan, diskusi kelompok yang dimediasi komputer memberikan tingkat kepuasan dan hubungan yang sama dengan FtF. Anggota grup Rumah Ramah Rubella bebas menulis komentar maupun pembaharuan status terkait isu yang mereka cermati (Widiasari, 2016).

Peneliti melihat bahwa respon pujian tersebut untuk menciptakan sebuah kepercayaan dari satu individu kepada individu lainnya, sehingga apa yang disampaikan tersebut mendapatkan kepercayaan dari orang lain dan dihargai, sehingga mendapat penilaian yang positif (SH, N, \& SK, 2015). Hal itu menunjukkan bahwa karakteristik CMC dalam jejaring sosial sebagai sarana untuk melepaskan eksistensi diri yang tidak terfasilitasi di dunia riil. Media memfasilitasi pengguna untuk mendapatkan aktivitasnya dengan lebih bebas (Intan, 2015).

Media menjadi ruang untuk pelampiasan secara emosional. Hal itu menunjukkan bahwa pengguna merasa nyaman melalui komunikasi media online. Perasaan malu, gugup, dan diam agar terhindar dari pandangan negatif 
dapat dihindari dengan interaksi tanpa harus takut mendapat penilaian buruk dari orang lain. Melalui penjelasan di atas, jejaring sosial seperti Fecbook melalui grup Rumah Ramah Rubella dapat dimanfaatkan sebagai media yang efektif bagi individu dan memiliki kebebasan dalam berekspresi (Soliha, 2015). Keuntungan adanya KDO adalah kenyamanan, anonimitas, dan pilihan respons ganda, yang tidak dapat ditemukan dalam kelompok tatap muka (Turner, 2017). Sehingga orang tua yang berbagi cerita anaknya lebih bebas dan nyaman dalam mengekspresikan perasaan guna mendaptakan dukungan dan motivasi dari anggota lain.

Keempat, promosi kesehatan menjadi proses pemberdayaan dan edukasi kepada masyarakat untuk lebiih peduli terhadap diri sendiri, keluarga dan lingkungan. Melalui media interaktif pesan komunikasi akan lebih menarik untuk disampaikan dan dipahami oleh masyarakat luas (Wibowo \& Suryani, 2013). Rumah Ramah Rubella memanfaatkan grup Facebook sebagai media promosi berkaitan dengan kesehatan yang terdiri dari promosi barang ,jasa dan donasi.

Meningkatkan kesadaran masyarakat dan memperbaiki fasilitas kesehatan melalui promosi penting unutk dilakukan. WHO berusaha untuk meningkatkan kemampuan masyarakat dalam memelihara dan menjaga kesehatan. Masyarakat harus mencapai indikator kesehatan yang ideal baik secara fisik, mental dan sosial (Saraswati, 2011).

Pesan persuasif atau ajakan dalam promosi imunisasi MR dapat diihat melalui postingan anggota yang menggunakaan video, tulisan maupun gambar yang diposting di wall grup. Salah satu nya adalah video animasi Upin-Ipin yang berjudul "Hapuskan Virus". Walaupun animasi tersebut berasal dari negara Malaysia, namun cukup popular di masyarakat Indonesia khususnya anak-anak. Pesan yang disampaikan tentang bahaya Rubella dan pentingnya imunisasi dapat dilihat melalui video tersebut. Peneliti melihat bahwa melalui video animasi pesan komunikasi dapat tersampaikan dan juga lebih menarik, hal itu berdasarkan postingan anggota grup yang mengajak anggota lain untuk melakukan imunisasi MR. Promosi imunisasi juga terlihat melalui postinggan anggota yang membagikan 4 video kampanye imunisasi yang menjelaskan mekanisme vaksin MR, dampak Campak Rubella, manfaat imunisasi melalui video animasi yang lebih menarik dan mudah dipahami, sehingga anggota akan terdorong untuk segera melakukan imunisasi pada anaknya. Selain melalui video animasi, promosi juga menggunkan tagar (\#) dengan pesan ajakan \#CegahCampakRubella \#EndMeaslesRubella, \#ImunisasiBisa. Melalui grup Facebook tagar tersebut merupakan salah satu bentuk tanda 
dalam jejaring sosial yang berfungsi sebagai medium pembawa pesan. namun juga hendak menanamkan pesan tertentu dalam pikiran penerima, tagar tersebut dapat digunakan anggota grup agar turut serta mengajak imunisasi MR secara bersama-sama.

Promosi di grup Rumah Ramah Rubella juga terdiri dari barang dan jasa antara lain promosi kesehatan berupa barang terdiri dari penjualan madu, alat bantu berjalan, alat bantu dengar. Sedangkan promosi jasa menawarkan spa bayi. Walaupun ada promosi yang tidak berkaitan dengan kesehatan yaitu penjualan boneka dan bimbingan belajar untuk anak. Peneliti melihat promosi barang dan jasa yang diposting memungkinkan anggota yang

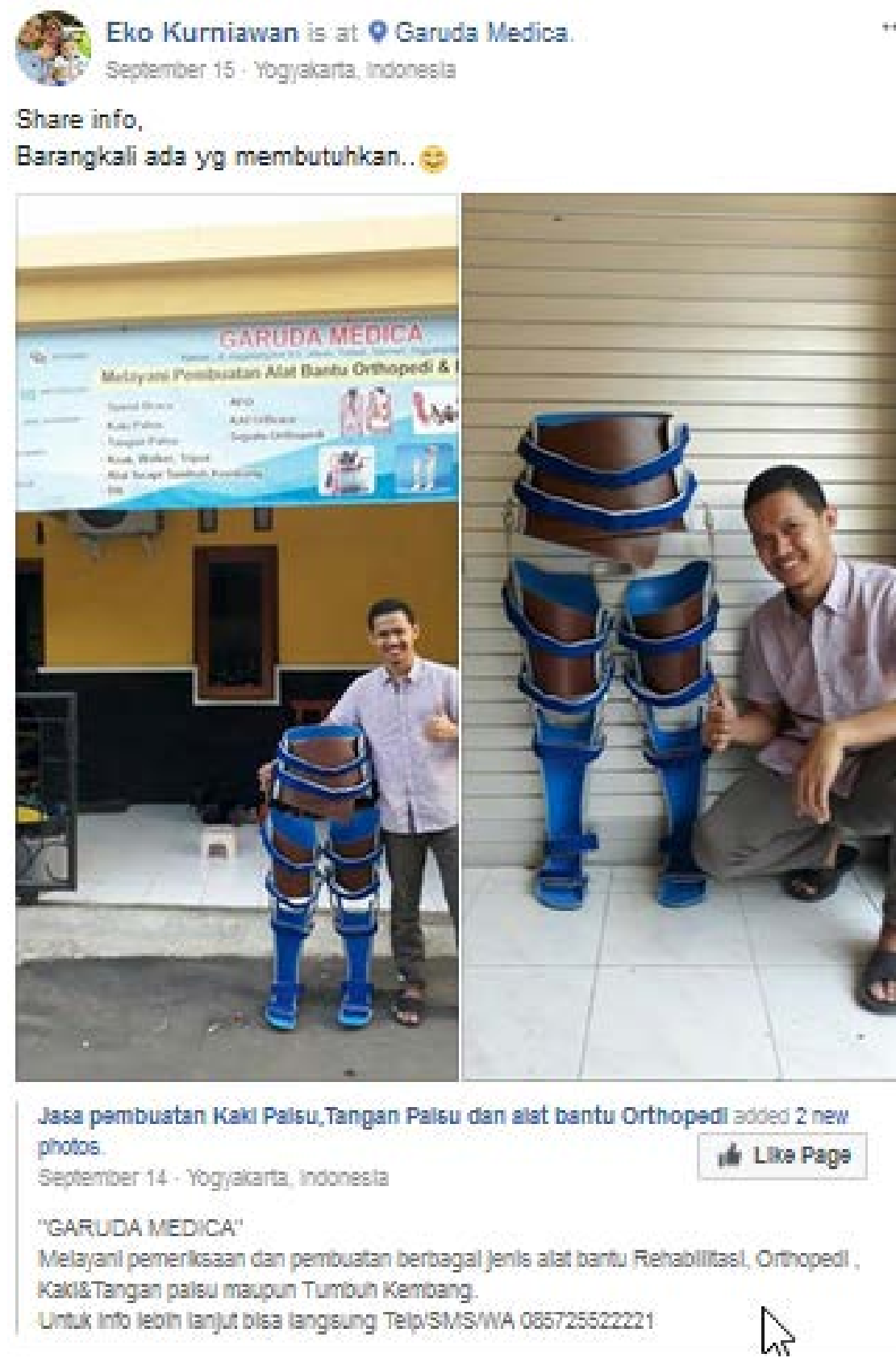

Sumber: Facebook, 2018

\section{Gambar 5 Postingan Promosi Barang}


membutuhkan alat kesehatan mendapatkan informasi dan terdorong yang berguna untuk kemudahan anaknya dalam proses penyembuhan seperti pada gambar 5. Promosi merupakan usaha persuasi agar anggota grup berminat dan membeli produk yang ditawarkan. Penelitian yang berjudul "Peran Facebook sebagai Media Komunikasi Bisnis Online (Studi Deskriptif Kualitatif Peran Facebook sebagai Media Komunikasi Bisnis Online” menunjukkan bahwa media sosial Facebook bermanfaat sebagai proses komunikasi yang mendekatkan antara produsen dan konsumennya (Gemilang, 2011). Fitur grup memungkinkan anggota Rumah Ramah Rubella menawarkan produk-produk kesehatan kepada anggota lain. Facebook kemudian dipandang sangat efektif untuk promosi barang maupun jasa (Muttaqin, 2011).

Selain itu Rumah Ramah Rubella memanfaatkan grup Facebook sebagai media donasi. Donasi merupakan hadiah atau pemberian secara cuma-cuma kepada seseorang atau organisasi. Modal donasi ini merupakan bantuan yang diberikan tanpa ada perjanjian atau syarat apapun (Jabbar, 2014). Donasi biasanya bisa berupa uang atau barang yang diberikan secara sukarela. Dalam postingan anggota grup, peneliti melihat grup Facebook di manfaatkan sebagai sarana untuk donasi berupa barang. Donasi tersebut merujuk pada sebuah link yang menyajikan informasi, prosedur maupun ketentuan untuk dapat berpartisipasi, misalnya donasi dari www.starkeyhearingfoundation. org salah satu organisasi asal Amerika Serikat yang memberikan alat bantu dengar kepada yang membutuhkan. Selain itu, ada bentuk donasi yang bersumber dari perorangan dengan mendonasikan alat standing secara gratis disaat anaknya kesulitan berdiri karena keterbatasan fisik. Donasi biasanya tidak berkaitan dengan profit atau keuntungan pribadi. Donasi juga merupakan bentuk dukungan Instrumentasl. Dukungan instrumental berupa bantuan secara nyata baik berupa donasi uang maupun barang yang diberikan kepada orang lain (SH et al., 2015).

Dukungan Instrumental atau dukungan secara konkrit meliputi bantuan secara langsung. Biasanya dukungan ini, lebih sering diberikan oleh teman atau rekan kerja, seperti bantuan untuk menyelesaikan tugas yang menumpuk atau meminjamkan uang atau lainlain Dukungan ini, menggambarkan tersedianya barang-barang (materi) atau adanya pelayanan dari orang lain yang dapat membantu individu dalam menyelesaikan masalahnya. Grup Facebook Rumah Ramah Rubella memberikan akses kepada anggotanya untuk menerima donasi bagi yang membutuhkan melalui tindakan konkrit. 


\section{SIMPULAN}

Kelompok dukungan online (KDO) merupakan komunitas yang dibentuk untuk membangun interakasi, meminta maupun memberi dukungan dalam dunia maya, yang difasilitasi oleh media berbasis internet. Anggota KDO yang ada dalam grup Facebook Rumah Ramah Rubella memanfaatkan berbagai fitur grup berupa postingan status, gambar, video, maupun akses file, sebagai bentuk dukungan informasi, emosional, ruang eksprsi diri dan sarana promosi kesehatan. KDO sangat berguna untuk menghubungkan individu dengan orangorang lain yang memiliki masalah kesehatan yang serupa, membantu individu memahami situasi dalam mencari alternatif pemecahan masalah atau tindakan yang akan diambil. Dalam konteks program imunisasi anggota KDO terdorong untuk melakukan imunisasi MR sebagai tindakan pencegahan penyakit Campak dan Rubella pada bayi maupun dewasa.

Penelitian ini diharapkan dapat memberikan gambaranmengenaipemanfaatan grup Facebook Rumah Ramah Rubella sebagai kelompok dukungan online (KDO) seputar penyakit Campak Rubella, imunisasi MR, maupun penyakit secara umum. Selanjutnya, disarankan untuk dilakukan penelitian selanjutnya yang diharapkan dapat melihat kelompok dukungan online (KDO) dalam jejaring sosial Facebook dengan wawancara yang mendalam.

\section{DAFTAR PUSTAKA}

Abrahamson, K., Keefe, B., \& Chou, W. Y. S. (2015). Communicating about cancer through Facebook: a qualitative analysis of a breast cancer awareness page. Journal of Health Communication, 20(2), 237-243. https://doi.org/10.1080/10810730.2014.92 7034

Aldita, D. (2014). Analisis isi film wag the dog tentang pelanggaran-pelanggaran kode etik humas. Dunia Komunikasi, 2(4), 75-87.

Barker, K. K. (2008). Electronic support groups, patient-consumers, and medicalization: the case of contested illness. Journal of Health and Social Behavior, 49(1), 20-36. https:// doi.org/10.1177/002214650804900103

Fadhila, S. R. (2017). Apakah vaksin mengandung babi? Retrieved march 20, 2020, from Indonesian Pediatic Society website: http://www.idai.or.id/ artikel/klinik/imunisasi/apakah-vaksinmengandung-babi

Feng, Y., \& Xie, W. (2014). Digital divide 2.0: the role of social networking sites in seeking health information online from a longitudinal perspective. Journal of Health Communication, 20(1), 1-9. https://doi. org/0.1080/10810730.2014.906522

Fitrya, S. N. T. A. (2017). Pengungkapan identitias diri melalui media sosial: studi mengenai etnografi virtual melalui virtual vlog. Universitas Hasanuddin.

Gemilang, R. D. A. (2011). Peran facebook sebagai media komunikasi bisnis online (studi deskriptif kualitatif peran facebook sebagai media komunikasi bisnis online. Universitas Pembangunan Nasional "Veteran." 
Intan, T. (2015). Motif pelajar SMAN 1 Wungu Madiun dalam penggunaan media sosial. Komunikatif Jurnal Ilmiah Komunikasi, 4(1). https://doi.org/10.33508/jk.v4i1.1625

Jabbar, H. A. (2014). 42-63. Jabbar, H. A. (2014). Pengaruh modal sendiri, modal pinjaman dan volume usaha terhadap sisa hasil usaha (studi kasus pada koperasi di kabupaten Sukoharjo Tahun 2012). Universitas Muhamadiyah Surakarta.

JE, C. (2014). Social networking in online support groups for health: how online social networking benefits patients. Journal of Health Communication, 19(6), 639-659. https://doi.org/10.1080/10810730.2012.75 7396

Kemenkes. (2018). Situasi campak dan rubella di Indonesia. Retrieved from http://www. depkes.go.id/article/view/18110600003/ situasi-campak-dan-rubella-di-indonesia. html

Kisekka, V., Han, W., \& Sharman, R. (2014). Utilizing the uses and gratification theory to understand patients use of online support groups. Illinois Experts, 20th Americas Conference on Information Systems, A. United States.: Illinois Experts.

Lestaluhu, S. Y.(2017).Dukungan sosial melalui media sosial (analisis isi kualitatif pesan dukungan sosial pada halaman facebook Rumah Zakat Official). Universitas Muhammadiyah Surakarta.

Mala, P. A. (2016). Manajemen kesan melalui foto selfie dalam facebook: studi fenomenologi pada mahasiswa ilmu komunikasi UMS. Komuniti: Jurnal Komunikasi Dan Teknologi Informasi. https://doi.org/https://doi.org/10.23917/ komuniti.v8i1.2933

Mayfield, A. (2008). What is social media. London: iCrossing.
Muttaqin, Z. (2011). Facebook marketing dalam komunikasi pemasaran modern. Teknologi, 1(2), 103-109.

Myrick, J. G., Holton, A., Himelboim, I., \& Love, B. (2015). \#Stupidcancer: exploring a typology of social support and the role of emotional expression in a social media community. Health Communication, 31(5), 1-10. https://doi.org/10.1080/10410236.20 14.981664

Octavianti, M.(2012). Menumbuhkan kesadaran merek produk melalui media sosial (studi kasus mengenai optimalisasi penggunaan "twitter" sebagai upaya menumbuhkan kesadaran merek Maicih "keripik singkong pedas asli kota Bandung"). Jurnal Kajian Komunikasi, 2(2), 178-194.

Oktafiana, R. (2016). Dukungan sosial keluarga, sekolah, dan masyarakat bagi kemandirian ekonomi difabel grahita (studi kasus difabel grahita di sekolah luar biasa Dharma Bhakti Piyungan). UIN Sunan Kalijaga Jogyakarta.

Prasetyo, H. (2010). Cyber community, cyber cultures: arsitektur sosial baru masyarakat modern. ULTIMA Comm, 2(2). https://doi. org/https://doi.org/10.31937/ultimacomm. v2i2.190

Purba, J., Yulianto, A., \& Widyanti, E. (2007). Pengaruh dukungan sosial terhadap burnout pada guru. Jurnal Psikologi, 5(1).

Rahmania, N. Z., \& Pamungkas, I. N. . (2018). Komunikasi interpersonal komunitas online www.rumahtaaruf.com. Jurnal Manajemen Komunikasi, 3(1), 51-66. https://doi.org/10.24198/jmk.v3i1.12032

Santoso, B. B. (2017). Apakah vaksin aman bagi anak. Retrieved March 20, 2020, from Indonesian Pediatic Society website: http:// www.idai.or.id/artikel/klinik/imunisasi/ apakah-vaksin-aman-bagi-anak 
Saraswati, L. K. (2011). Pengaruh promosi kesehatan terhadap pengetahuan tentang kanker serviks dan partisipasi wanita dalam deteksi dini kanker serviks (di Mojosongo Rw 22 Surakarta). Universitas Sebelas Maret.

SH, M. R., N, A., \& SK, B. (2015). Seeking social support on Facebook for children with Autism Spectrum Disorders (ASDs). Journal of Medical Informatics, 84(5), 1-16. https://doi.org/10.1016/j. ijmedinf.2015.01.015

Sugiyono. (2016). Memahami penelitian kualitatif. Bandung: Alfabeta.

Turner, J. A. (2017). Online support groups: the good, the bad, and the motivated. Journal of Consumer Health on the Internet, 21(1), 11-25. https://doi.org/10.1080/15398285.2 017.1279930
Utami, A. M. V., Lestari, M. T., \& Putra, A. (2015). Pergeseran budaya komunikasi pada era media baru (studi etnografi virtual penggunaan line oleh digital natives). E-Proceeding of Management, 4042-4050.

Utami, N. M. S. N. (2013). Hubungan antara dukungan sosial keluarga dengan penerimaan diri individu yang mengalami asma. Jurnal Psikologi Udayana, 1(1), 12-21.

Wibowo, S., \& Suryani, D. (2013). Pengaruh promosi kesehatan metode audio visual dan metode buku saku terhadap peningkatan pengetahuan penggunaan monosodium glutamat (MSG) pada Ibu Rumah Tangga. Kesmas, 7(2), 67-74.

Widiasari, A. (2016). Facebook sebagai komunikasi yang dimediasi komputer. Jurnal InterAct, 5(2), 63-82. 